LENTERA PENDIDIKAN, EDISI X, NO. 1, JUNI 2007 (83-94)

\title{
BELAJAR SEBAGAI SUATU PROSES AKTIVITAS KOGNITIF
}

\author{
Oleh: Wahyuni Ismail
}

\begin{abstract}
Learning is a word often heard and it is an activity done by everyone started since birth, childhood, teens, up to the adulthood. It can be stated that learning is a process occurring from birth to death. It is an activity done a long the life. Furthermore, Learning is a process occurring in various aspects. How can the learning process occurring according to human cognitive activity? According to psychology, learning process is formed due the presence of the psychological ability of the internal aspect of human to respond the stimulus. The response is then processed through indra. From indra, perception, association, reproduction, fantasy, memory, thinking, are all formed to rich what is called intellectual ability. Cognitive activity process is different between one individual to another.
\end{abstract}

KEYWORDS: Belajar, aktivitas kognitif.

PENDIDIKAN pada hakekatnya adalah usaha sadar untuk mengembangkan potensi sumber daya manusia khususnya peserta didik dangan cara mendorong dan memfasilitasi kegiatan belajar mereka. Secara detail, dalam Undang-undang RI Nomor: 20 Tahun 2003 tentang Sistem Pendidikan Nasional Bab 1 Pasal 1 dinyatakan bahwa pendidikan adalah usaha sadar dan terencana untuk mewujudkan suasana belajar dan proses belajar agar peserta didik secara aktif mengembangkan potensi dirinya untuk memiliki kekuatan spiritual keagamaan, pengendalian diri, kepribadian, kecerdasan, akhlak mulia serta keterampilan yang diperlukan dirinya, masyarakat, bangsa dan negara. ${ }^{1}$ Sesuai dengan hal tersebut, maka belajar memegang peranan penting. Belajar adalah kegiatan yang berproses dan merupakan unsur yang sangat fundamental dalam penyeleggaraan setiap jenis dan jenjang pendidikan. Hal ini berarti bahwa berhasil atau gagalnya pencapaian tujuan pendidikan itu amat bergantung pada proses belajar yang dialami siswa baik ketika berada di lingkungan pendidikan formal maupun berada di lingkungan rumah sendiri.

Perspektif Islam dalam Q.S. Mujadilah (58): 11 juga menekankan bahwa belajar merupakan kewajiban bagi setiap orang beriman agar 
memperoleh ilmu pengetahuan dalam rangka meningkatkan derajat kehidupan mereka. Manusia selain sebagai makhluk yang berakal juga manusia adalah makhluk yang berjiwa. Kehidupan kejiwaannya itu direfleksikan dalam tingkah laku atau aktivitas. Apabila manusia melakukan suatu aktivitas, maka manusia menginterpretasikan situasi itu berkaitan dengan tujuan yang ingin dicapai. Hasil dari interpretasi itu adalah keyakinan yang bersifat positif atau negatif yang disebut sebagai penilaian kognitif.

Penilaian kognitif memiliki dua bagian penting yaitu proses penilaian dan keyakinan yang dihasilkannya. ${ }^{2}$ Menurut Walgito kemampuan kejiwaan yang merupakan aktivitas manusia diklasifikasikan atas tiga hal: yaitu: kognitif, kemampuan jiwa manusia menerima stimulus dari luar yang berkaitan dengan pengenalan; afektif, kemampuan manusia untuk melahirkan apa yang terjadi dalam jiwanya yang berkaian dengan emosi dan perasaan; dan konatif, yang berkaitan dengan motif dan psikomotorik manusia. Menurutnya, meskipun kemampuan kejiwaan itu diklasifikasikan, tetapi harus diingat bahwa jiwa manusia itu merupakan suatu kesatuan atau totalitas. Pembahasan tulisan ini terfokus pada belajar sebagai proses aktivitas kognitif. Psikologi kognitif menurut Solso berkaitan dengan bagaimana kita memperoleh informasi tentang dunia, bagaimana informasi itu ditransformasikan sebagai pengetahuan, bagaimana informasi itu disimpan dan bagaimana pengetahuan tersebut dimanfaatkan untuk mengarahkan tingkah laku atau aktivitas manusia. ${ }^{3}$ Sebagai penegasan dapat diformulasi dalam bentuk sebuah pertanyaan, bagaimanakah proses belajar merupakan aktivitas kognitif pada manusia itu terjadi?

\section{BELAJAR SEBAGAI AKTIVITAS KOGNITIF}

Belajar pada dasarnya adalah tahapan perubahan perilaku siswa yang relatif positif dan menetap sebagai hasil interaksi dengan lingkungan yang melibatkan proses kognitif. Aktivitas kognitif manusia meliputi persepsi atau pengamatan, tanggapan atau bayangan, asosiasi dan reproduksi, fantasi, memori atau ingatan, berpikir, dan kecerdasan. Proses aktivitas tersebut terjadi sebagai akibat dari stimulus yang diterima oleh manusia dan manusia melakukan respon terhadap stimulus tersebut sehingga mempunyai arti. Adapun belajar sebagai proses pembentukan aktivitas kognitif dapat digambarkan sebagai berikut; Stimulus $\rightarrow$ Penginderaan (fisiologis dan psikologis) $\rightarrow$ Persepsi $\rightarrow$ Tanggapan/Respon $\rightarrow$ Asosiasi dan Reproduksi $\rightarrow$ Fantasi $\rightarrow$ Memori $\rightarrow$ Berpikir $\rightarrow$ Inteligensi. 


\section{Persepsi}

Sebelum persepsi itu terbentuk, maka terlebih dahulu ada penginderaan. Proses penginderaan akan berlangsung setiap saat, pada waktu individu menerima stimulus melalui alat indera yaitu melalui mata sebagai alat penglihatan, telinga sebagai alat pendengar, hidung sebagai alat pembau, lidah sebagai alat pengecap, dan kulit sebagai alat perabaan yang digunakan untuk menerima stimulus dari luar individu. Alat indera tersebut merupakan alat penghubung antara individu dengan dunia luarnya. Stimulus yang diindera itu oleh individu diorganisasikan dan diinterpretasikan sehingga individu menyadari dan mengerti apa yang diindera itu dan proses ini disebut persepsi. ${ }^{4}$ Persepsi adalah suatu penelitian bagaimana manusia menintegrasikan sensasi ke dalam percepts (percepts adalah hasil dari proses perceptual) obyek dan bagaimana manusia itu selanjutnya menggunakan percepts itu untuk mengenali dunia. ${ }^{5}$ Dapat dikatakan bahwa persepsi adalah hasil pengamatan manusia dengan dunia luarnya sehingga manusia dapat meberikan pemahaman atau pengertian terhadap hasil pengamatannya tersebut. Oleh karena itu, dalam penginderaan orang menghubungkan dengan stimulus sedangkan persepsi dihubungkan dengan obyek.

Beberapa faktor yang berperan dalam terbentuknya persepsi yaitu obyek atau stimulus yang diterima, alat indera dan susunan syaraf pusat, serta perhatian. Proses terjadinya persepsi adalah obyek menimbulkan stimulus dan stimulus mengenai alat indera. Proses stimulus mengenai alat indera ini merupakan proses fisik atau kealaman. Stimulus yang diterima oleh alat indera diteruskan oleh syaraf sensorik ke otak, hal ini disebut proses fisiologis. Kemudian terjadilah proses di otak sebagai pusat kesadaran sehingga individu menyadari apa yang dilihat, didengar, atau yang diraba. Proses yang terjadi dalam otak atau pusat kesadaran ini disebut proses psikologis. Respon sebagai akibat dari persepsi dapat diambil oleh individu dalam berbagai macam bentuk.

Diperlukan beberapa macam aspek pengaturan terhadap obyek yang diamati agar orientasi persepsi dapat berhasil dengan baik6, yaitu: Aspek pengaturan dari segi ruang; bahwa persepsi dilukiskan dalam pengertian: atas-bawah, kiri-kanan, jauh-dekat, dan sebagainya. Jika tak ada pengaturan ruang, maka orientasi persepsi individu tidak sempurna. Misal melihat mahasiswa-Dimana? Aspek pengaturan dari segi waktu; persepsi dilukiskan dalam pemahaman: masa lampau, masa kini, dan masa yang akan datang. Misalnya melihat mahasiswa-Kapan? Aspek pengaturan dari segi Gestalt; obyek yang diamati dipersepsi sebagai suatu kesatuan yang 
utuh bukan sebagai elemen-elemen. Misalnya melihat mahasiswa sebagai suatu manusia yang utuh bukan dilihat hanya kapala atau badannya saja. Aspek pengaturan dari segi arti; obyek yang dipersepsi diberi arti menurut artinya bagi kita. Misal pabrik dan sekolah dilihat dari segi bangunan mempunyai banyak persamaannya, tetapi dilihat dari artinya menunjukkan hal yang sangat berbeda.

Tidak semua stimulus akan direspon oleh individu; respon diberikan jika ada kesesuaian atau yang menarik perhatian individu. Stimulus yang diberikan respon tergantung pada bermacam-macam faktor di antaranya adalah perhatian individu.

\section{Tanggapan/Bayangan}

Tanggapan sebagai salah satu fungsi jiwa dapat diartikan sebagai gambaran atau bayangan yang tertinggal dalam diri manusia sesudah melakukan persepsi terhadap suatu obyek atau peristiwa. Menurut Suryabrata tanggapan selain menghidupkan kembali apa yang telah dipersepsi juga dapat mengantisipasi sesuatu yang akan datang atau yang terjadi saat ini. ${ }^{7}$

Berdasasarkan indera yang digunakan untuk malakukan persepsi, maka tanggapan dapat dibedakan: ${ }^{2}$ tanggapan visual, merupakan hasil persepsi yang dilakukan indera mata; tanggapan auditif, hasil pengamatan indera telinga; tanggapan olfaktorik, hasil indera hidung; tanggapan gustative, hasil indera lidah; tanggapan taktil, hasil indera kulit.

Tanggapan memiliki peranan penting dalam proses belajar anak didik, khususnya dalam proses memperoleh pengertian. Urutan proses itu adalah: persepsi-bayangan pengiring (bayangan yang timbul sesudah kita melihat suatu warna untuk beberapa saat, kemudian mengalihkan pandangan ke latar belakang putih. Jika bayangan yang tampak sesuai warna obyek aslinya, maka bayangan pengiring bersifat positif dan sebaliknya); bayangan eiditik (bayangan yang sangat jelas dan hidup sehingga orang memiliki tanggapan seolah-olah megamati kembali obyeknya, bayangan eiditik ini biasanya terdapat pada anak-anak, wanita, seniman, dan orang-orang genius); tanggapan-pengertian/pemahaman terhadap suatu obyek.

\section{Asosiasi dan Reproduksi}

Asosiasi adalah hubungan antara tanggapan yang satu dengan tanggapan yang lain. Reproduksi yaitu pemunculan kembali tanggapantanggapan dari keadaan di bawah sadar menuju alam kesadaran. Cara memunculkan kembali dapat terjadi karena kemauan individu dan tidak 
menurut kemauan individu, yaitu jika tanggapan itu dengan sendirinya mendesak dan muncul di kesadaran.

Menurut Walgito dalam hal asosiasi-reproduksi berlaku lima hukum: ${ }^{9}$ hukum berurutan yaitu beberapa tanggapan yang dialami seseorang secara berurutan akan membentuk asosiasi, misalnya jika kita mengucapkan 1,2,3, maka kita teringat 4,5,6; hukum sama waktu, tanggapan yang muncul bersamaan dalam kesadaran akan terasosiasi bersama, contoh jika seseorang mengingat dosennya, maka teringat pula cara mengajarnya; hukum persamaan, tanggapan yang hampir sama berasosiasi dan direproduksikan ke kesadaran, contoh melihat harimau teringat akan kucing; hukum berlawanan ialah tanggapan yang berlawanan akan berasosiasi dan saling mereproduksikan satu dengan yang lain; hukum kontiguitas ialah jika tanggapan itu sudah bersentuhan, maka terjadi asosiasi di antara tanggapan-tanggapan.

\section{Fantasi}

Fantasi adalah kemampuan jiwa untuk membentuk tanggapan baru atas tanggapan yang telah ada. Kemampuan jiwa individu untuk berkreasi dalam khayalan sebelum dituangkan dalam dunia nyata. Fantasi dapat diklasifikasikan atas: ${ }^{10}$ 1) fantasi yang tidak disadari, terjadi jika individu tidak sadar telah dituntun oleh fantasinya, individu melampaui dunia riil. Misalnya melamun; 2) fantasi yang disadari, terjadi jika individu menyadari akan fantasinya. Fantasi jenis ini terbagi atas dua yaitu fantasi menciptakan sesuatu, contoh desainer pakaian menciptakan model pakaian; fantasi terpimpin, individu mengikuti fantasi yang diciptakan orang lain, contoh orang yang menonton film.

Berdasarkan cara individu berfantasi, dibedakan atas: 11 fantasi yang mengabstraksi yaitu cara orang berfantasi dengan mengabstraksikan beberapa bagian, sehingga ada bagian yang dihilangkan; fantasi yang mendeterminasi, misalnya anak belum pernah melihat harimau tetapi telah melihat kucing, maka kucing digunakan sebagai bahan untuk memberikan pemahaman tentang harimau; fantasi yang mengkombinasi yaitu cara berfantasi dengan mengkombinasikan tanggapan-tanggapan yang ada pada individu yang bersangkutan, contohnya ingin membangun rumah dengan mengkombinasikan model Eropa dengan atap model rumah Minangkabau.

Kegunaan fantasi adalah merupakan sarana memahami orang lain, individu berpeluang melepaskan diri dari keterikatannya dengan ruang dan waktu sehingga membantu manusia untuk bercita-cita. ${ }^{12}$ Menurut Dakir, faktor-faktor penyebab timbulnya fantasi yaitu adanya waktu 
senggang, tidak ada aktivitas tertentu, adanya harapan atau cita-cita, adanya berbagai kesulitan pemecahan masalah, sedang dirundung asmara, adanya kelemahan pribadi yang menyebabkan untuk membuat defense mechanism atau mekanisme pertahanan diri. ${ }^{13}$ Tes yang sering digunakan untuk mengetes fantasi yaitu, ${ }^{14}$ a) tes TAT ialah tes yang berupa gambargambar dan testeer disuruh bercerita tentang gambar tersebut, b) tes kemustahilan, tes yang berbentuk gambar atau cerita yang mustahil terjadi, c) Heilbronner Wirsma Test ialah tes berupa seri gambar yang makin lama makin sempurna, d) Rorschach Test, tes berwujud gambar-gambar dan testeer disuruh menginterpretasikan gambar itu. Fantasi lebih bersifat subyaktif, tanggapan yang terjadi karena fantasi disebut tanggapan fantasi.

\section{Memory}

Memory adalah kemampuan jiwa individu untuk memasukkan/ learning, menyimpan/retention dan menimbulkan kembali/remembering halhal masa lalu. Istilah lain yang sering juga dipakai adalah memasukkan/ encoding, menyimpan/strorage, dan menimbulkan kembali/retrieval terhadap persepsi atau peristiwa lampau. ${ }^{15}$

Jika individu melakukan persepsi, maka apa yang dipersepsi itu sama sekali tidak hilang melainkan disimpan dalam memory dan jika diperlukan pada suatu waktu dapat ditimbulkan kembali. Terkadang apa yang dipersepsi dapat pula tidak langsung ditimbulkan di alam kesadaran sebagai memory output, tetapi disimpan dalam ingatan dalam waktu yang lama dan jika diperlukan dapat dimunculkan kembali ke alam kesadaran. Hal ini disebut long term memory oleh Morgan dkk.16 yang jarak pemunculan kembali di atas 30 detik sedangkan short term memory jarak waktu antara pemasukan stimulus dan pemunculan kembali sebagai memory output berkisar 20-30 detik. Informasi dalam memori jangka pendek cenderung disandikan secara akustik dan sandi visual, fakta yang paling menonjol tentang memori jangka pendek adalah kapasitas penyimpanannya yang terbatas 2-7 butir kata. Berdasarkan kemampuan masing-masing individu dalam menerima kesan, maka ada orang yang mudah memasukkan kesan demikian pula sebaliknya.

Beberapa metode yang digunakan untuk menimbulkan kesan-kesan dengan cepat di antaranya metode ganslem, yaitu metode belajar secara keseluruhan, untuk menghafal sesuatu yang hanya sedikit; metode teillem yaitu metode belajar bagian demi bagian untuk menghafal bahan yang banyak, caranya dipelajari sedikit demi sedikit lalu digabungkan; metode vermittelende ialah kombinasi antara metode ganslem dan teillem. Lebih lanjut Ahmadi mengemukakan tentang metode penyelidikan memori yaitu 
metode mempelajari, metode mempelajari kembali, metode rekonstruksi, mengenal kembali, metode mengingat kambali dan metode asosiasi berpasangan. ${ }^{17}$

Kemampuan memori manusia itu terbatas yaitu tidak semua yang disimpan dalam memori dapat ditimbulkan kembali di alam kesadaran. Hal inilah yang meyebabkan manusia mengalami kelupaan. Kelupaan terjadi karena fungsi fisiologis sangat berpengaruh pada pusat kesadaran yaitu otak. Seperti penelitian yang dilakukan oleh Ebbinghaus dan Boreas menunjukkan bahwa kekuatan mengingat pada manusia makin lama semakin berkurang yang akhirnya manusia dapat mengalami kelupaan. Subyek yang ditugaskan menghafal kata-kata akan menghasilkan kemampuan memori, sebagai berikut: setelah 0 jam penyimpanan $=58 \%, 1$ jam penyimpanan $=44 \%, 9$ jam penyimpanan $36 \%, 24$ jam penyimpanan $=34 \%$, 48 jam penyimpanan $=28 \%$, setelah 6 hari penyimpanan $=25 \%, 31$ hari penyimpanan $=21 \% .18$ Kesimpulan hasil penelitiannya menunjukkan bahwa kelupaan dapat terjadi karena materi yang disimpan tidak sering dimunculkan kembali akhirnya manusia menjadi lupa. Walgito mengatakan ada dua macam teori tentang kelupaan, yaitu; ${ }^{19}$ 1) teori Atropi, kelupaan terjadi karena jejak-jejak ingatan/memory traces telah lama mengendap, tidak dimunculkan kembali ke kesadaran; dan 2) teori interferensi, terjadi karena memory traces saling mengganggu, saling bercampur aduk sehingga menimbulkan kelupaan, teori ini terbagi lagi menjadi (1) interferensi proaktif bahwa materi yang mendahului akan mengganggu materi yang datang kemudian; dan (2) interferensi retroaktif bahwa materi yang dipelajari kemudian dapat mengganggu materi yang dipelajari dahulu. Korelasi antara apa yang diingat dengan yang dilupa adalah berbanding terbalik, artinya bahwa semakin banyak yang diingat, maka semakin sedikit yang dilupakan demikian pula sebaliknya.

\section{Berpikir}

Pencapaian tertinggi spesies manusia adalah berasal dari kemampuannya untuk melakukan pemikiran kompleks dan mengkomunikasikannya. Proses berpikir memiliki banyak aktivitas mental, pada semua kasus berpikir dapat dianggap sebagai "bahasa otak". Suatu cara berpikir bersesuaian dengan aliran kalimat sehingga kita tampaknya mendengar dipikiran kita. Hal ini dinamakan pikiran propossional karena mengekspresikan usul atau tuntutan); cara lain bersesuain dengan citra visual sehingga kita dapat melihat alam pikiran kita, inilah yang disebut pikiran imajiner; cara yang bersesuaian dengan urutan pergerakan mental yang disebut pikiran motorik. ${ }^{20}$ Salah satu sifat berpikir adalah tujuan yang ingin 
diraih guna mendapatkan pemecahan masalah. Berpikir dapat disebut sebagai pemrosesan informasi dari stimulus yang ada sampai problem solving. Berpikir merupakan proses dinamis karena manusia aktif dalam menghadapi hal-hal abstrak. Pada proses berpikir manusia membuat korelasi antara obyek dengan pengetahuan yang sudah dimiliki dalam wujud pengertian atau pemahaman. Pada umumnya simbol yang digunakan dalam proses berpikir berupa kata-kata atau bahasa. Dengan begitu, sering dikatakan bahwa bahasa dan berpikir saling berkaitan. Artinya, manusia yang berpikir menyumbangkan pendapat, pemahaman, keputusan atau kesimpulan dengan mengguanakan bahasa.

Menurut Crow \& Crow, ada dua jenis berpikir, yaitu; ${ }^{21}$ 1) berpikir reflektif yaitu kemampuan jiwa manusia dalam menyeleksi pengetahuan yang pernah didapat yang relevan dengan tujuan masalah. Lebih lanjut dikatakan bahwa proses-proses mental yang menyertai berpikir reflektif ialah direction: perhatian dan minat yang diarahkan pada tujuan; interpretation: interpretasi pada hubungan-hubungan yang terdapat pada tujuan; selection: mengingat kembali dan memilih sejumlah pengetahuan yang pernah didapatkan; insight: adanya pemahaman manusia; creation: pembentukan pola-pola mental baru; criticism: penilaian terhadap kesanggupan penyelesaian masalah. Langkah-langkah berpikir reflektif yaitu manusia merasakan adanya masalah, melokalisasi dan memberi batasan kesukaran pemahaman terhadap masalah, menemukan korelasi memformulasikan hipotesis-hipotesis, mengevaluasi hipotesis, menerapkan cara problem solving yaitu menerima atau menolak kesimpulan; 2) berpikir kreatif adalah kemampuan jiwa menerima, memberi alasan kritis dan mempergunakan hasilnya dalam problem solving. Tahapan berpikir kreatif yaitu tahap persiapan, tingkat seseorang memformulasikan masalah dan mengumpulkan data; tahap inkubasi, tingkat berlangsungya masalah dalam jiwa manusia; tahap iluminasi, tingkat pemahaman yaitu masalah sudah terpecahkan; tahap evaluasi yaitu mengecek apakah pemecahan yang diperoleh cocok atau tidak; tahap revisi, melakukan perbaikan terhadap hasil.

Tujuan berpikir adalah mencari pemecahan masalah yang sedang dihadapi. Berdasarkan data yang ada, maka diambillah suatu kesimpulan. Bermacam-macam cara penarikan kesimpulan, yaitu:22 a) kesimpulan analogi yaitu kesimpulan yang diambil berdasarkan adanya persamaan dari suatu peristiwa dengan peristiwa lainnya, b) kesimpulan induktif yaitu kesimpulan yang diambil dari hal yang bersifat khusus ke hal yang bersifat umum, c) kesimpulan deduktif adalah kesimpulan yang ditarik atas peristiwa yang bersifat umum menuju peristiwa yang bersifat khusus. 
Contoh penarikan kesimpulan deduktif adalah dengan silogisme, di dalamnya terdapat tiga pendapat yaitu premis mayor, premis minor, dan kesimpulan. Jadi, dalam silogisme kesimpulan yang ditarik berdasarkan premis mayor dan premis minor. Pada hakekatnya manusia senantiasa melakukan aktivitas berpikir baik untuk bahan perenungan, menciptakan kreativitas, maupun memecahkan masalah yang dihadapi.

\section{Intellegensi}

Umumnya manusia mengenal inteligensi sebagai istilah yang menggambarkan kecerdasan, kepintaran, maupun kemampuan untuk memecahkan masalah. Intellegensi berasal dari kata Latin intelligere yang berarti mengorganisasikan, menghubungkan atau menyatukan satu dengan yang lain. ${ }^{23}$ Gardner mengemukakan bahwa intelegensi adalah suatu kapasistas untuk memecahkan masalah dan untuk menciptakan produk di lingkungan yang kondusif dan alamiah. Teorinya multiple intellegences yang terdiri atas 9 jenis inteligensi yaitu;

1. Kecerdasan verbal/word smart ialah suatu kemampuan menggunakan kata secara efektif baik secara lisan misalnya pendongeng, orator, politisi maupun secara tertulis seperti wartawan, sastrawan, dan editor. Menurut Buzan, kecerdasan verbal dapat dimanfaatkan untuk menemukan dan menjelajahi dunia baru; menggairahkan imajinasi; mempelajari lebih jauh kehebatan otak dan bagaimana memfungsikannya; merasakan kembali nikmatnya bermain-main dengan kata dan makna kata; mempelajari rahasia cara membaca cepat dan cara memahami sesuatu secara lebih tajam; mempelajari cara-cara mempengaruhi orang lewat ucapan dan tulisan.

2. Kecerdasan matematis logis/number smart yaitu kemampuan menggunakan angka dengan baik seperti ahli matematika, akuntan pajak, ahli statistik dan melakukan penalaran yang benar misalnya ahli pemrogram komputer.

3. Kecerdasan spasial/picture smart adalah suatu kemampuan mempersepsi dunia spasial visual dan dapat mentransformasikannya seperti arsitek, dekorator, penemu, dan seniman.

4. Kecerdasan kinestesis-jasmani/body smart yaitu suatu kapasitas menggunakan seluruh tubuh untuk mengekspresikan ide dan perasaan seperti aktor/aktris, atlit, penari, pantomin serta keterampilan menggunakan tangan untuk menciptakan atau mengubah sesuatu misalnya pengrajin, pematung, ahli mekanik, dokter bedah.

5. Kecerdasan musikal/music smart yaitu kemampuan menangani bentukbentuk dengan cara mempersepsi: penikmat musik, membedakan: 
kritikus musik, menggubah: komposer, dan mengekspresikan seperti penyanyi.

6. Kecerdasan naturalis/nature smart yaitu keahlian mengenali dan mengkategorikan spesies flora dan fauna di lingkungan alam sekitar seperti pencinta alam, ahli lingkungan hidup, pencinta binatang dan tanaman.

7. Kecerdasan interpersonal/people smart suatu kompetensi mem-persepsi dan membedakan suasana hati, maksud, motivasi, serta perasaan orang lain. Kecerdasan ini diperlukan untuk meningkatkan sosialisasi.

8. Kecerdasan interpersonal/self smart adalah suatu kemampuan untuk mengenali diri sendiri dan bertindak berdasarkan pemahaman itu, kecerdasan ini dilakukan untuk perenungan mendalam atau berkonsentrasi. Kecerdasan ini berhubungan dengan kecerdasan emosional.

9. Kecerdasan eksistensial yaitu kemampuan pengetahuan tentang keberadaan manusia, tetapi kecerdasaan ini masih dipertajam keberadaannya. Lebih lanjut Hernowo mengemukakan bahwa tidak ada kecerdasan yang berdiri sendiri saat digunakan oleh individu. Penggunaan satu kecerdasan akan melibatkan dua atau lebih kecerdasan lainnya. Semakin banyak individu memanfaatkan kecerdasannya, maka masalah yang dihadapi akan cepat terselesaikan. ${ }^{24}$

Alfred Binet sebagai perintis pengukuran inteligensi bersama Theodore Simon mendefinisikan inteligensi yang terdiri tiga komponen yaitu kemampuan untuk mengarahkan pikiran/tindakan, kemampuan untuk mengubah arah tindakan bila tindakan itu telah dilaksanakan, kemampuan untuk mengkritik diri sendiri. Thorndike mengklasifikasikan inteligensi menjadi tiga komponen, yaitu:25 1) kemampuan abstraksi, suatu kemampuan untuk bekerja dengan menggunakan gagasan dan simbol; 2) kemampuan mekanis, suatu kemampuan menggunakan alat-alat mekanis yang memerlukan aktivitas indera gerak atau sensory-motoris; 3) kemampuan sosial, suatu kemampuan untuk membina hubungan dengan orang lain secara efektif. Manusia menggunakan test inteligensi jika ingin mengetahui taraf inteligensinya. Orang pertama yang menciptakan tes inteligensi adalah Binet tahun 1905 kemudin direvisi oleh Binet sendiri 1908 sebagai revisi pertama dan tahun 1911 sebagai revisi kedua. Tahun 1916 test Binet direvisi dan diadaptasi disesuaikan penggunaanya di Amerika yang dikenal dengan revisi Terman dari Stanford University yang dikenal Stanford Revision, juga dikenal dengan Test Intelligenci Stanford Binet. Ternyata test inteligensi terus mengalami perkembangan, tahun 1939 David Weschler menciptakan individual intelligence test. Tahun 1949 diciptakan test Weschler Intelligence Scale for Children yang dikenal dengan test Inteligensi WISC yang khusus untuk anak-anak. ${ }^{26}$ Sebagai kesimpulan 
inteligensi dapat diartikan sebagai suatu kompetensi jiwa manusia untuk dapat beradaptasi dengan cepat dan tepat dengan situasi yang baru.

\section{PENUTUP}

Belajar pada hakekatnya adalah proses perubahan tingkah laku manusia untuk pengembangan dirinya. Setiap individu untuk merealisasikan tingkah lakunya akan ditunjukkan melalui gejala kejiwaan yang ditimbulkannya. Gejala kejiwaan tersebut meliputi kognitif, afektif, dan konatif. Belajar sebagai suatu proses aktivitas kognitif pada manusia terjadi sebagai akibat dari stimulus yang diterima oleh manusia kemudian melakukan respon terhadap stimulus tersebut melalui proses penginderaan sehingga terbentuk persepsi. Setelah proses persepsi timbullah tanggapan atau respon kemudian menjadi proses asosiasi, lalu terbentuklah fantasi dari fantasi menuju ke memori lalu ke proses berpikir, dari proses berpikir lalu tercipta inteligensi. Demikianlah bagaimana poses belajar sebagai aktivitas kognitif terjadi pada manusia, yaitu melalui kemampuan kejiwaan kognitif.

\section{CATATAN AKHIR:}

1. Muhibbin Syah, Psikologi Belajar, Jakarta: Raja Grafindo Persada, 2006, h. 1.

2. Rita Atkinson, Atkinson Richard, Smith Edward, Bem Daryl., a.b. Kusuma Widjaja, Pengantar Psikologi, jilid I, edisi 11, Batam: Interaksara, 1987, h. 96.

3. Stanberg Solso, Cognitive Psychology, Allyn Bacon: Needhams Height, 1995, h. 2.

4. Bimo Walgito, Pengantar Psikologi Umum, Yogyakarta: Andi Offset, 2002, h. 69.

5. Rita Atkinson, Pengantar Psikologi, jilid I, edisi 11, Batam: Interaksara, 1987, h. 276.

6. Sumadi Suryabrata, Psikologi Pendidikan, Jakarta: CV. Rajawali, 1987, h. 19.

7. Sumadi Suryabrata, Psikologi Pendidikan, h. 36.

8. Mahmud Dimyati, Psikologi Pendidikan, Jakarta: Departemen Pendidikan dan Kebudayaan Dirjen Perguruan Tinggi, 1989, h. 3-4.

9. Bimo Walgito, Pengantar Psikologi Umum, h. 113.

10. Rumini dkk., Psikologi Pendidikan, Yogyakarta: UPP UNY, 1995, h. 6.

11. Bimo Walgito, Pengantar Psikologi Umum, h. 115.

12. Rumini dkk., Psikologi Pendidikan, h. 7.

13. Dakir, Dasar-Dasar Psikologi, Yogyakarta: FIP IKIP, 1984, h. 74.

14. Bimo Walgito, Pengantar Psikologi Umum, h. 116.

15. Bimo Walgito, Pengantar Psikologi Umum, h. 118.

16. Bimo Walgito, Pengantar Psikologi Umum, h. 119.

17. Abu Ahmadi, Psikologi Umum, Jakarta: Rineka Cipta, 1991, h. 73-74.

18. Dakir, Dasar-Dasar Psikologi, h. 66-67.

19. Bimo Walgito, Pengantar Psikologi Umum, h. 126. 
20. Rita Atkinson, Atkinson Richard, Smith Edward, Bem Daryl., a.b. Kusuma Widjaja, Pengantar Psikologi, h. 548.

21. Crow, Lester D., and Crow, Alice. a.b. Abd. Rachman Abror, Psikologi Pendidikan, Yogyakarta: Nurcahaya, 1984, h.

22. Bimo Walgito, Pengantar Psikologi Umum, h. 142-144.

23. Bimo Walgito, Pengantar Psikologi Umum, h. 146.

24. Hernowo, Andaikan Buku itu Sepotong Pizza, Rangsangan Baru untuk Melejitkan Word Smart, Bandung: Kaifa, 2004, h. 126.

25. Saifuddin Azwar, Pengantar Psikologi Inteligensi, Yogyakarta: Pustaka Pelajar, 1995, h. 5.

26. Bimo Walgito, Pengantar Psikologi Umum, h. 152.

\section{DAFTAR PUSTAKA:}

Ahmadi, Abu, Psikologi Umum, Jakarta: Rineka Cipta, 1991.

Atkinson, Rita, Atkinson Richard, Smith Edward, Bem Daryl., a.b. Kusuma Widjaja, Pengantar Psikologi, Jilid I, Edisi 11, Batam: Interaksara, 1987.

Azwar, Saifuddin, Pengantar Psikologi Inteligensi, Yogyakarta: Pustaka Pelajar, 1995.

Chernov, Fred B., a.b. Sukoco, The Sharper Mind, Jakarta: Gramedia Pustaka Utama, 1997.

Crow, Lester D., and Crow, Alice. a.b. Abd. Rachman Abror, Psikologi Pendidikan, Yogyakarta: Nurcahaya, 1984.

Dakir, Dasar-Dasar Psikologi, Yogyakarta: FIP IKIP, 1984.

Dimyati, Mahmud, Psikologi Pendidikan, Jakarta: Departemen Pendidikan dan Kebudayaan Dirjen Perguruan Tinggi, 1989.

Djamarah, Syaiful Bahri, Psikologi Belajar, Jakarta: Rineke Cipta, 2002.

Hernowo, Andaikan Buku itu Sepotong Pizza, Rangsangan Baru untuk Melejitkan Word Smart, Bandung: Kaifa, 2004.

Rumini, dkk, Psikologi Pendidikan, Yogyakarta: UPP UNY, 1995.

Solso, Stanberg, Cognitive Psychology. Allyn Bacon: Needhams Height, 1995.

Suryabrata, Sumadi, Psikologi Pendidikan, Jakarta: CV. Rajawali, 1987.

Syah, Muhibbin, Psikologi Belajar, Jakarta: RajaGrafindo Persada, 2006.

Walgito, Bimo, Pengantar Psikologi Umum, Yogyakarta: Andi Offset, 2002. 